\title{
Adaptive Technologies for Medicinal Herbs Cultivation and Evaluation of the Obtained Raw Material Quality
}

\author{
Svetlana N. VITYAZ ${ }^{1 *}$, Maria S. RAKINA ${ }^{1}$, Olga G. POZDNYAKOVA ${ }^{1}$, \\ and Maria A. KAZAKOVA ${ }^{1}$ \\ ${ }^{1}$ Kuzbass State Agricultural Academy, Kemerovo, Russian Federation \\ *Correspondence: svetlana_vityaz@mail.ru
}

\begin{abstract}
The article presents the results of the influence of various methods of cultivation of medicinal herbs in the forest-steppe zone of the Kemerovo region on their productivity and quality of raw materials. For research, spotted milk thistle, calendula officinalis, and chamomile were selected. Baskets (calendula officinalis, chamomile) and fruits (milk thistle) were collected from plants as medicinal raw materials. The effect of biofertilizer application and seed treatment with a humic preparation was investigated. It has been established that the use of biofertilizer in conjunction with pre-sowing treatment of seeds with humates leads to an increase in yield elements in all studied medicinal crops. Compared to the control, the productivity of the variant with this treatment was 1.27 times higher for spotted milk thistle $\left(11 \mathrm{~g} / \mathrm{m}^{2}\right), 14.4 \mathrm{~g} / \mathrm{m}^{2}$ for chamomile and $24.7 \mathrm{~g} / \mathrm{m}^{2}$ for calendula officinalis. Thus, the use of organic fertilizers together with the pre-sowing treatment of seed with a humic preparation completely eliminates the use of mineral fertilizers of industrial production at cultivating spotted thistle, calendula officinalis and chamomile in the forest-steppe zone of the Kemerovo region.
\end{abstract}

Keywords: medicinal herbs, adaptive technologies, productivity, quality indicators, biologically active substances.

\section{Introduction}

Providing high-quality medicinal raw materials is a priority for the development of the country's agro-industrial complex. The cultivation of medicinal raw materials under industrial conditions has a number of advantages, among which the maximum preservation of the natural thickets of phytocenoses and obtaining a guaranteed volume of phyto raw materials in the required time frame. Many medicinal plants often have simple agro-technical methods of cultivation, unpretentiousness to the soil-climatic conditions of growth, and high ecological plasticity [1, p. 8].

Kemerovo region as most of the northern constituent entities of the Russian Federation is referred to the risky farming zone, which is confirmed by the strong dependence of crop production on natural and climatic conditions. Since industrial cultivation of medicinal herbs in Kuzbass today is poorly developed, and the need for medicinal raw materials is high, there is a need to develop a technology for cultivating medicinal herbs under conditions that allow obtaining the maximum yield with minimal energy consumption in this soil-climatic zone. In this regard, the development and improvement of methods for 
cultivating medicinal herbs for plant materials for the conditions of the forest-steppe zone of the Kemerovo region is relevant, has scientific and practical value.

The aim of the study was to assess the effect of biofertilizer introduced into the soil and seed treatment with a humic preparation on the yield elements and the quality of medicinal plant materials obtained in the Kemerovo region.

\section{Materials and Methods}

The following types of medicinal plants were selected for the study: thistle spotted (Sílybum mariánum) variety Panacea (originator - S.P. Kayuda), calendula officinalis (Caléndula officinális) variety Kalta (VILAR), chamomile pharmacy (Matricāria chamomīlla) variety Podmoskovnaya (VILAR) [2, p. 40].

Grass sowing was carried out in prepared soil in the second decade of May 2018. The sowing rate of each type of medicinal plant and the depth of seed placement were in accordance with the recommended norms [1, p. 40].

The soils of the experimental field are represented by chernozem podzolized soil with heavy granulometric composition. The zone parent rocks are loesslike heavy loam and clay (Table 1 ).

From agrochemical indicators it follows that the humus content in the soil is high $-8.1 \%$, $\mathrm{pH}$ salt -5.3 , slightly acidic soils. The degree of soil saturation with bases $\left(\Sigma \mathrm{Ca}^{+}+\mathrm{Mg}^{+}\right)$is high $-90 \%$. The availability of mobile phosphorus is high, mobile potassium is very high.

To ensure the normal growth and development of plants, enhanced nitrogen and phosphorus nutrition is necessary. To ensure the mineral nutrition of the plants, livestock wastes were used as bio-fertilizers, composted in order to comply with safe sanitary standards in terms of the presence of microbes and the degradation of weeds' ability to germinate.

Table 1. Agrochemical parameters of the soils of the experimental field

\begin{tabular}{l|c|c|c}
\hline \multicolumn{1}{c}{ Indicators } & Content & Units & Methods \\
\hline Humus & 8,1 & $\%$ & by Tyurin \\
\hline $\mathrm{pH}$ salt & 5,3 & $\mathrm{mEq} / 100 \mathrm{~g}$ of soil & by Kappen \\
\hline Hydrolytic acidity & 4,2 & $\mathrm{mEq} / 100 \mathrm{~g}$ of soil & by Kappen \\
\hline $\begin{array}{l}\text { Amount of } \\
\text { exchangeable bases }\end{array}$ & 29,4 & $\%$ & calculating \\
\hline $\begin{array}{l}\text { Degree of soil } \\
\text { saturation with } \\
\text { bases }\end{array}$ & 90 & $\mathrm{mg} / \mathrm{kg}$ of soil & by Chirikov \\
\hline Labile phosphorus & 135 & $\mathrm{mg} / \mathrm{kg}$ of soil & by Chirikov \\
\hline Labile potassium & 181 & &
\end{tabular}


Some scientific works $[3$, p. $110 ; 4$, p. $22 ; 5$, p. 27] note a positive effect of pre-sowing treatment of seed material with humic preparations on the growth, development of plants, as well as the quality of agricultural products. In most works $[6, p .68]$, the authors recommend the use of preparations in a solution concentration of $0.001 \%$.

To study the role of organic nutrition and pre-sowing treatment of seed material in the formation of productivity elements and quality of medicinal plant materials, the following experimental options were laid down:

- Option 1 (control) - sowing against a natural background;

- Option 2 - introduction of biofertilizer under the main treatment, $20 \mathrm{t} / \mathrm{ha}$ or $2 \mathrm{~kg}$ per $1 \mathrm{~m}^{2}$;

- Option 3 - introduction of biofertilizer under the main treatment, $20 \mathrm{t} / \mathrm{ha}$ or $2 \mathrm{~kg}$ per $1 \mathrm{~m}^{2}$ and pre-sowing seed treatment with a humic preparation (at a solution concentration of $0.001 \%$ ).

The experiment was repeated three times. The plot area for each option was $18 \mathrm{~m}^{2}$. Every time experimental field occupied $54 \mathrm{~m}^{2}$. Placement of options is consistent [7, p. 129]. The sowing method is ordinary with a row spacing of $45 \mathrm{~cm}$. The main tillage was carried out manually to a depth of $10-15 \mathrm{~cm}$. The predecessor is perennial grasses.

Before sowing, the seeds were treated with the preparation with the trade name "Humat Baikal", TU 2189-004-71788256-2015, certificate of conformity № ROSS RU. AU 64.H08241, manufacturer of LLC AgroTechGUMAT. The preparation contains a complex of potassium and sodium salts of humic and fulvic acids $84-86 \%$, potassium content of at least $9 \%$, solubility of at least $92 \%$.

The calculation of fertilizer application rates was carried out according to the method proposed by V.N. Yefimov [8, p. 209].

Anthodes (calendula officinalis, chamomile) and bearings (milk thistle) were collected from plants as medicinal raw materials. When determining the yield elements for all types of medicinal plants, the following indicators were taken into account: the number of anthodes per plant (pcs) and yield $\left(\mathrm{g} / \mathrm{m}^{2}\right)$. Two thistles for spotted milk thistle were further analyzed as the weight of 1000 seeds $(\mathrm{g})$ and the weight of seeds from one plant (g).

Before sowing, to determine the quality of the seed, seed germination was determined according to GOST 12038-84.

The quality and authenticity of the raw materials were evaluated by indicators: humidity (GOST R 54951-2012), nitrogen and crude protein (GOST 13496.4-93), crude fat content (GOST 13496.15-97), crude ash (GOST 26226-95).

During the experiment, lead and cadmium (GOST 30178-96), mercury (GOST 26927-86), arsenic (GOST 26930-86), dry matter (GOST 31640-2012), carotenoids (GOST R 540582010), essential oils (OFS.1.5.3.0010.15), basic biologically active substances (OFS.1.2.3.0017.15; FS.2.5.0037.15; FS.2.5.0035.15; FS.2.5.0030.15) were determined in the collected medicinal raw materials.

The resulting material was processed on a personal computer using software package programs Statistica and SNEDEKOR [9]. For each parameter studied (germination energy, 
laboratory germination of seeds, quality of medicinal plant raw materials) the average value, the error of representativeness of the average were calculated. The significance of differences in the elements of plant productivity according to the experimental variants was determined according to $\mathrm{HCP}_{05}[10$, p. 186].

\section{Results and Discussion}

Laboratory germination of seeds of the studied medicinal herbs varied from $82 \%$ to $95 \%$, which indicates compliance with the requirements of GOST 12038-84. The highest laboratory germination of seeds was observed in Sílybum marianum.

The analysis results of the studied medicinal crop yield elements are presented in table 2. It is established that the yield elements increased from the first to the third option of the experiment for all the studied crops. Thus, the number of anthodes per plant increased from 5.3 to 7.1 pieces (milk thistle), from 12.4 to 17.1 pieces (apricot chamomile), from 101.2 to 110.3 pieces (calendula medicinal). The weight of 1000 seeds of milk thistle in the second and third options of the experiment was significantly higher compared with the control by $2.8 \mathrm{~g}$ and $7.28 \mathrm{~g}$, and the mass of seeds from one plant by $0.7 \mathrm{~g}$ and $3 \mathrm{~g}$, respectively.

Studies have shown that the use of biofertilizer together with the pre-sowing seed treatment with humates leads to an increase in yield elements in all studied medicinal crops. The yields in the third experiment compared with the control were significantly higher: for thistle - in 1.27 times (by $11 \mathrm{~g} / \mathrm{m}^{2}$ ), chamomile pharmacy - by $14.4 \mathrm{~g} / \mathrm{m}^{2}$, and calendula officinalis - by $24,7 \mathrm{~g} / \mathrm{m}^{2}$.

The results obtained (Table 2) indicate a positive dynamics of the yield elements of the studied medicinal crops under conditions of applying biological fertilizers to the soil, together with the pre-sowing treatment of seed material with a humic preparation.

Table 2. Yield elements of medicinal plan

\begin{tabular}{|c|c|c|c|c|}
\hline $\begin{array}{c}\text { Option of the } \\
\text { experiment }\end{array}$ & $\begin{array}{c}\text { Number of } \\
\text { anthodes per one } \\
\text { plant }\end{array}$ & $\begin{array}{l}\text { Weight of } \\
1000 \text { seeds, } 9\end{array}$ & $\begin{array}{l}\text { Weight of } \\
\text { seeds from } \\
\text { one plant, g }\end{array}$ & Yield $\left(\mathrm{g} / \mathrm{m}^{2}\right)$ \\
\hline \multicolumn{5}{|l|}{ milk thistle } \\
\hline I option & 5,3 & 29,6 & 8,8 & 40 \\
\hline II option & 5,7 & $32,4^{*}$ & 9,5 & $47^{*}$ \\
\hline III option & $7,1^{*}$ & $36,8^{*}$ & $11,8^{*}$ & $51^{*}$ \\
\hline $\mathrm{HCP}_{05}$ & 1,03 & 2,40 & 1,57 & 3,42 \\
\hline \multicolumn{5}{|c|}{ chamomile pharmacy } \\
\hline I option & 12,4 & - & - & 167,1 \\
\hline II option & 14,8 & - & - & 174,6 \\
\hline III option & $17,1^{*}$ & - & - & $181,5^{*}$ \\
\hline $\mathrm{HCP}_{05}$ & 4,91 & - & - & 14,64 \\
\hline
\end{tabular}




\begin{tabular}{l|c|c|c|c}
\hline \multicolumn{1}{c}{$\begin{array}{c}\text { Option of the } \\
\text { experiment }\end{array}$} & $\begin{array}{c}\text { Number of } \\
\text { anthodes per one } \\
\text { plant }\end{array}$ & $\begin{array}{c}\text { Weight of } \\
\mathbf{1 0 0 0} \text { seeds, }\end{array}$ & $\begin{array}{c}\text { Weight of } \\
\text { seeds from } \\
\text { one plant, } \mathbf{g}\end{array}$ & Yield $\left(\mathbf{g} / \mathbf{m}^{\mathbf{2}}\right)$ \\
\hline calendula officinalis & 101,2 & - & - & 160,5 \\
\hline I option & 107,1 & - & - & 177,7 \\
\hline II option & $\mathbf{1 1 0 , 3 ^ { * }}$ & - & - & $\mathbf{1 8 5 , 2 *}$ \\
\hline III option & 7,37 & - & - & 24,82 \\
\hline HCP & & & - & \\
\hline
\end{tabular}

Note * - significant differences in indicators relative to the first option of the experiment.

The introduced nutrients contribute to increasing the yield of inflorescences. Thus, the use of organic fertilizers allows getting stable yields.

In scientific papers, there were found no acceptable level of toxic elements directly for medicinal plants. Therefore, indicators of SanPin 2.3.2. 1078-01 dated 11.14.2001/22.03.02 were taken as regulated ones: lead - not more than $6.0 \mathrm{mg} / \mathrm{kg}$; cadmium - $1.0 \mathrm{mg} / \mathrm{kg}$; mercury - $0.1 \mathrm{mg} / \mathrm{kg}$. MAC of arsenic in food raw materials and food products $-0.2 \mathrm{mg} / \mathrm{kg}$.

Below there are the results of the assessment of the quality of medicinal plant materials of milk thistle, chamomile pharmacy, and calendula officinalis (Table 3). The results obtained indicate that in the studied samples the content of lead, cadmium, mercury and arsenic did not exceed the permissible level, which indicates the safety of medicinal raw materials. At the same time, it was found that the use of humic preparation led to a slight decrease in heavy metals in the third option.

Table 3. Content of heavy metals in the raw materials of medicinal plants, $\mathrm{mg} / \mathrm{kg}$

\begin{tabular}{l|l|l|l|l}
\hline \multicolumn{1}{c}{ Samples } & Lead & Cadmium & Mercury & Arsenic \\
\hline milk thistle & 0,06 & 0,14 & 0,014 & 0,012 \\
\hline I option & 0,05 & 0,13 & 0,012 & 0,011 \\
\hline II option & 0,03 & 0,11 & 0,011 & 0,010 \\
\hline III option & 0,06 & 0,14 & 0,014 & 0,012 \\
\hline chamomile pharmacy & 0,12 & 0,012 & 0,010 \\
\hline I option & 0,05 & 0,11 & 0,011 & 0,011 \\
\hline II option & 0,06 & 0,11 & 0,03 & 0,007 \\
\hline III option & 0,12 & 0,09 & 0,03 & 0,006 \\
\hline calendula officinalis & 0,11 & \multicolumn{5}{l}{} \\
\hline I option & \multicolumn{5}{l}{} \\
\hline II option & 0 & & \\
\hline
\end{tabular}




\begin{tabular}{l|c|c|c|c}
\hline \multicolumn{1}{c}{ Samples } & Lead & Cadmium & Mercury & Arsenic \\
\hline III option & 0,08 & 0,07 & 0,03 & 0,007 \\
\hline MPC, mg/kg & 6,0 & - & 0,1 & 0,2 \\
\hline UEC, mg/kg & - & 1,0 & - & - \\
\hline
\end{tabular}

Note: there are no significant differences.

The quality and authenticity of the raw materials were evaluated by such indicators as moisture, ash, fat, protein.

One of the most important indicators by which the quality of the processed plant material judged is the dry matter content in it. According to literature data, the dry matter content in plant objects depends not only on the type and grade of raw materials, but also on climatic conditions (weather) [11, p. 417]. Based on the results obtained, it was found that the use of biofertilizer and pre-sowing treatment of seed material with a humic preparation did not significantly affect the percentage of dry matter in the studied medicinal crops (Table 4). Differences in the dry matter content in the options did not exceed $1.35 \%$ in the bearings of milk thistle, $0.47 \%$ and $0.06 \%$ in the inflorescences of chamomile and calendula officinalis, respectively.

Table 4. Physic-chemical indicators of medicinal plant materials, $\%$

\begin{tabular}{|c|c|c|c|c|c|c|}
\hline \multirow[b]{2}{*}{ Plant } & \multirow[b]{2}{*}{$\begin{array}{c}\text { Experience } \\
\text { option }\end{array}$} & \multicolumn{5}{|c|}{ Indicators } \\
\hline & & $\begin{array}{c}\text { Initial } \\
\text { moisture, } \\
\%\end{array}$ & $\begin{array}{c}\text { Dry } \\
\text { matter, \% }\end{array}$ & $\begin{array}{c}\text { Crude } \\
\text { protein, } \\
\%\end{array}$ & $\begin{array}{c}\text { Crude Fat, } \\
\%\end{array}$ & $\begin{array}{c}\text { Crude Ash, } \\
\%\end{array}$ \\
\hline \multirow[t]{3}{*}{ Milk thistle } & I option & 6,47 & 93,53 & 15,76 & 10,35 & 5,25 \\
\hline & II option & 5,89 & 94,11 & 15,79 & 10,99 & 5,27 \\
\hline & III option & 5,12 & 94,88 & 15,83 & 11,01 & 5,31 \\
\hline \multirow{3}{*}{$\begin{array}{l}\text { Chamomile } \\
\text { pharmacy }\end{array}$} & I option & 9,89 & 90,11 & 2,42 & 1,52 & 9,61 \\
\hline & II option & 9,67 & 90,33 & 2,41 & 1,51 & 9,93 \\
\hline & III option & 9,42 & 90,58 & 2,43 & 1,53 & 10,12 \\
\hline \multirow{3}{*}{$\begin{array}{l}\text { Calendula } \\
\text { officinalis }\end{array}$} & I option & 8,74 & 91,26 & 2,64 & 0,4 & 7,91 \\
\hline & II option & 8,68 & 91,32 & 2,74 & 0,4 & 8,55 \\
\hline & III option & 8,70 & 91,30 & 2,82 & 0,5 & 8,16 \\
\hline
\end{tabular}

Note: there are no significant differences.

Analyzing the results of the crude protein content in medicinal raw materials of all the studied cultures, there were found no significant differences for the options.

When analyzing the content of crude fat in the studied plant raw materials, it was found that the greatest changes in the variants were observed in the plant raw materials of milk thistle. Namely, in the raw materials of the second and third options, compared with the 
control of crude fat, it was $0.64 \%$ and $0.66 \%$ more, respectively. In the inflorescences of chamomile pharmacy and calendula officinalis, differences did not exceed $0.02 \%$ and $0.1 \%$, respectively.

When analyzing the indicators of crude ash in the analyzed raw materials (table. 4) it was found that the selected methods also did not have a significant impact on this indicator. So in options of milk thistle, it varied according to the options within $5.25 \pm 0.1 \ldots 5.31 \pm 0.3 \%$, of chamomile pharmacy - $9.61 \pm 1.2 \ldots 10.12 \pm 1.9 \%$, calendula officinalis $-7.91 \pm 0.7 \ldots 8.55 \pm 1.1 \%$.

Medicinal plants are rich in biologically active substances (BAS). This determines their healing properties. The quantitative content of biologically active substances in medicinal plant materials was determined by high performance liquid chromatography. The results of the determination of biologically active substances in medicinal plant materials based on extracts of these medicinal plants are presented in table 5.

According to literature data $[12$, p. 119] it is known that the active substances in the bearings of milk thistle are the sum of flavolignans and flavonoids, called silymarin. According to TU 64-4-30-81, milk thistle bearings must contain at least $2.7 \%$ silibinin. The results of the analysis of the quality of plant raw materials showed (Table 5) that the obtained raw material complies with the applicable standards and does not have significant differences in options.

Table 5. The results of determining the quantitative content of biologically active substances in medicinal plant raw material, \%

\begin{tabular}{|c|c|c|c|c|c|}
\hline \multirow{2}{*}{ № } & \multirow{2}{*}{$\begin{array}{c}\text { Name of } \\
\text { medicinal plant }\end{array}$} & \multirow{2}{*}{$\begin{array}{c}\text { Name of } \\
\text { biologically } \\
\text { active } \\
\text { substances }\end{array}$} & \multicolumn{3}{|c|}{$\begin{array}{c}\text { Content of biologically active substances in } \\
\text { medical plant raw material, \% }\end{array}$} \\
\hline & & & I option & II option & III option \\
\hline 1 & Milk thistle & Silibinin & $3,11 \pm 0,1$ & $3,18 \pm 0,1$ & $3,21 \pm 0,1$ \\
\hline \multirow{5}{*}{2} & \multirow{5}{*}{$\begin{array}{l}\text { Chamomile } \\
\text { pharmacy }\end{array}$} & Essential oil & $0,28 \pm 0,01$ & $0,29 \pm 0,01$ & $0,29 \pm 0,01$ \\
\hline & & Routine & $0,85 \pm 0,1$ & $0,89 \pm 0,1$ & $0,91 \pm 0,1$ \\
\hline & & Hamazulen & $14,67 \pm 0,1$ & $14,73 \pm 0,1$ & $14,78 \pm 0,1$ \\
\hline & & Coumarins & $3,00 \pm 0,1$ & $3,08 \pm 0,1$ & $3,11 \pm 0,1$ \\
\hline & & Cevitamic acid & $9,5 \pm 0,5$ & $10,73 \pm 1,2$ & $10,6 \pm 1,1$ \\
\hline \multirow{6}{*}{3} & \multirow{6}{*}{$\begin{array}{l}\text { Calendula } \\
\text { officinalis }\end{array}$} & Essential oil & $1,42 \pm 0,1$ & $1,45 \pm 0,1$ & $1,49 \pm 0,1$ \\
\hline & & Routine & $0,81 \pm 0,2$ & $0,79 \pm 0,1$ & $0,82 \pm 0,1$ \\
\hline & & Flavonoids & $4,35 \pm 0,1$ & $4,35 \pm 0,1$ & $4,37 \pm 0,1$ \\
\hline & & Caratinoids & $2,01 \pm 0,1$ & $2,11 \pm 0,1$ & $2,12 \pm 0,1$ \\
\hline & & $\beta$-carotene & $0,62 \pm 0,1$ & $0,61 \pm 0,1$ & $0,64 \pm 0,1$ \\
\hline & & Cevitamic acid & $1,42 \pm 0,1$ & $1,45 \pm 0,1$ & $1,49 \pm 0,2$ \\
\hline
\end{tabular}

Note: there are no significant differences. 
The therapeutic effect of chamomile pharmacy is determined by the presence of a complex of substances, primarily essential oil, flavonoids, coumarins, as well as sesquiterpenic lactone matricin, which under the action of acids, alkalis or water vapor turns into chamazulene - an anti-inflammatory and anti-allergic substance, therefore the matrixin is called prohamazulenom [13, p. 165]. The results of a chemical analysis of the content of biologically active substances in chamomile inflorescences showed (Table 3 ) that the obtained raw material complies with the applicable standards and does not have significant differences in options. A wide range of medicinal properties of calendula officinalis is manifested due to the presence of a large number of biologically active substances that are very different in chemical nature and pharmacological action: flavonoids, xanthophylls and carotenoids, essential oil, coumarins (scopoletin), watersoluble polysaccharides (14.75\%), triterpene saponins $2-10 \%$ and others [14, p. 787; 15 , p. $159 ; 16$, p. $83 ; 17$, p. 732$]$.

\section{Concluding Observations}

During the research, a positive dynamics of the yield elements of the studied medicinal crops based on agronomic methods of their cultivation was established. The yields of milk thistle, chamomile pharmacy, calendula officinalis in the options with the simultaneous use of two agricultural methods (option 2), compared with the control were higher on average by $11 \mathrm{~g} / \mathrm{m}^{2}$, by $14 \mathrm{~g} / \mathrm{m}^{2}$ and $24 \mathrm{~g} / \mathrm{m}^{2}$, respectively.

Moreover, the methods proposed in the work, contributing to an increase in productivity, did not significantly affect the quality of plant materials. In all the samples studied, the content of lead, cadmium, mercury and arsenic did not exceed the permissible level, which indicates the safety of the obtained medicinal raw materials. An analysis of the content of biologically active substances in the obtained medicinal plant raw materials, depending on agronomic methods of cultivation, showed that the amount of biologically active substances, depending on the experimental options, changed insignificantly and corresponded to the requirements for this type of raw material. So, the amount of silibinin in milk thistle ranged from 3.11 to $3.21 \%$, flavanoids in calendula officinalis from 4.35 to $4.37 \%$, the routine in chamomile from 0.79 to $0.82 \%$, depending on the option.

\section{Conclusion}

Thus, the use of organic fertilizers together with the pre-sowing treatment of seed material with a humic preparation allows obtaining stable crops when cultivating milk thistle, calendula officinalis, and chamomile pharmacy under conditions of a shallow experiment. However, in order to develop and improve the cultivation technology of the proposed assortment of medicinal crops in the conditions of a steppe zone of the Kemerovo region, it is advisable to continue research in this direction.

\section{References}

(1) Shalamova, E. L. The Technology of Medicinal Plant Cultivation: A Course of Lectures; Crop production and forestry; RIO GAGU: Gorno-Altaisk, Russia, 2010. 
(2) The Study of Medicinal Plants in the Botanical Garden of NPO "VILAR": Collection of Scientific Papers (in Russian); VILAR: Moscow, 1991.

(3) Kondratenko, E. P.; Sukhikh, A. S.; Verbitskaia, N. V.; Soboleva, O. M. Biostimulation and physicochemical properties of a sodium humate (in Russian). Chemistry of Plant Raw Materials 2016, 3, 109-118. https://doi.org/10.14258/jcprm.2016031185.

(4) Kondratenko, E. P.; Chumanova, N. N.; Sergeeva, I. A.; Pozdnyakova, O. G.; Voroshilin, R. A. Evaluation of the Reaction of Table Carrot to Pre-Treatment of Seeds by Humic Prepations (in Russian). Achievements of science and technology of the agro-industrial complex 2017, 31 (1), 22-25.

(5) Kondratenko, E. P.; Verbitskaya, N. V.; Izhmulkina, E. A.; Soboleva, O. M. Agroecological Evaluation of Spring Soft Wheat Reaction on Treatment by Humic Preparation Gumostim and Weather Conditions (in Russian). Vladimir land-farmer 2016, 4 (78), 26-30.

(6) Chumanova, N. N.; Scherer, D. V. The Effect of Humic Preparations on the Yield and Quality Characteristics of Oats in the Kemerovo Region (in Russian). Bulletin of the Kurgan State Agricultural Academy 2017, 1 (21), 65-68.

(7) Dospekhov, B. A. Methods of Field Experience (with the Basics of Statistical Processing of Research Results) (in Russian); Demand Book: Moscow, 2012.

(8) Efimov, V. N.; Donskikh, I. N.; Sinitsyn, G. I. Fertilizer Application System (in Russian); Kolos: Moscow, 1984.

(9) Sorokin, O. D. Applied Statistics on the Computer (in Russian), 2nd ed.; State Unitary Enterprise RPO SO RAAS: Krasnoobsk, Russia, 2010.

(10) Lakin, G. F. Biometrics (in Russian); Higher School: Moscow, 1980.

(11) Zagumennikov, V. B. Criteria for Cultivation Intensity of Medicinal Plants in the Conditions of the Non-Chernozem Zone of the Russian Federation (in Russian). In New non-traditional plants and prospects for their use: Materials of the VIII Int. symposium; RUDN: Moscow, 2009; pp 416-419.

(12) Pitkevich, E. S.; Lyzikov, A. N.; Tsaprilova, S. V. Milk Thistle - Silybum Marianum (L) (in Russian). Problems of Health and Ecology 2008, 4 (18), 119-126.

(13) Belenovskaya, L. M.; Budantsev, A. L. Genus Matricaria L. - Chamomile (in Russian). In Plant resources of Russia: Wild flowering plants, theircomponent composition and biological activity, Vol. 2; Tovarishchestvo nauchnykh izdanii KMK: Saint Petersburg, Russia, 2013.

(14) Shorin, N. V.; Kriklivaya, A. N.; Verkhovykh, A. Yu. Productivity of Medicinal Raw Material and Seeds of the Calendula of the Medicinal Variety Compactnaya in the Conditions of the Forest-Steppe Zone of the Omsk Region (in Russian). Young Scientist 2015, 9 (89), 786-791.

(15) Baghizadeh, A.; Ranjbar, S.; Gupta, V. K.; Asif, M.; Pourseyedi, S.; Karimi, M. J.; Mohammadinejad, R. Green Synthesis of Silver Nanoparticles Using Seed Extract of Calendula Officinalis in Liquid Phase. Journal of Molecular Liquids 2015, 207, 159163. https://doi.org/10.1016/j.molliq.2015.03.029. 
(16) Hindle, V. A.; Mathijssen-Kamman, A. A.; Stockhofe, N.; Cone, J. W. The Performance of Young Pigs Fed Different Amounts of Marigold (Calendula Officinalis) Meal; a Pilot Study. NJAS - Wageningen Journal of Life Sciences 2002, 50 (1), 83-94. https://doi.org/10.1016/S1573-5214(02)80005-7.

(17) Sólyomváry, A.; Mervai, Z.; Molnár-Perl, I.; Boldizsár, I. Specific Hydrolysis and Accumulation of Antiproliferative Lignans in the Fruit of Leuzea Carthamoides (Willd.) DC. Natural Product Research 2014, 28 (10), 732-739. https://doi.org/10.1080/14786419.2013.879473.

\section{Information about Authors}

Svetlana Nikolaevna viTYAZ: Ph.D. in Biology, Associate Professor, Head of the Department of Landscape Architecture, Kuzbass State Agricultural Academy; 5 Markovtsev Str., Kemerovo, 650056, Russia; e-mail: svetlana_vityaz@mail.ru.

Maria Sergeevna RAKINA: Ph.D. in Biology, Associate Professor, Department of Landscape Architecture, Kuzbass State Agricultural Academy; 5 Markovtsev Str., Kemerovo, 650056, Russia; e-mail: ra_machka@mail.ru.

Olga Georgievna POZDNYAKOVA: Ph.D. in Engineering, Associate Professor, Department of Landscape Architecture, Kuzbass State Agricultural Academy; 5 Markovtsev Str., Kemerovo, 650056, Russia; e-mail: 79502628552@ya.ru.

Maria Andreevna KAZAKOVA: Lecturer, Department of Landscape Architecture, Kuzbass State Agricultural Academy; 5 Markovtsev Str., Kemerovo, 650056, Russia; e-mail: mariya_kazakova.com@mail.ru. 